\title{
Understanding female and male
} empowerment in Burkina Faso using the project-level Women's Empowerment in Agriculture Index (pro-WEAl): a longitudinal
study

Benjamin T. Crookston ${ }^{1 *} \mathbb{D}$, Josh H. West ${ }^{1}$, Siena F. Davis ${ }^{1}$, P. Cougar Hall ${ }^{1}$, Greg Seymour ${ }^{2}$ and Bobbi L. Gray ${ }^{3}$

\begin{abstract}
Background: Achieving gender equality and women's empowerment is a major global priority. The purpose of this study was to determine whether the Building the Resilience of Vulnerable Communities in Burkina Faso (BRB) project, an agricultural development program, improved women's empowerment, as measured by the project-level Women's Empowerment in Agriculture Index (pro-WEAl).

Methods: This study used a longitudinal, quasi-experimental study design. Participants included both treatment and comparison groups (total $\mathrm{N}=751$ ) comprising female members of savings groups and their husbands or main male household member in Burkina Faso. All participants completed the pro-WEAl questionnaire at both baseline and endline. The treatment group received a comprehensive intervention package consisting of agriculture loans and services, microenterprise loans, and education, nutrition education, and women's empowerment programs including gender-based discussions designed to facilitate personalized changes in gender relations.
\end{abstract}

Results: The proportion of the treatment group achieving empowerment did not change from baseline for women, but improved substantially for men. Women from the comparison group saw an increase in empowerment at endline while men saw a substantial decrease. Gender parity was high for women in both groups at baseline and increased slightly at endline. Women were more likely to have adequate empowerment in input in productive decisions, group membership, and membership in influential groups than men while men were more likely to have adequate empowerment in attitudes about domestic violence, control over use of income, and work balance than women. Participants from the treatment group reported an increase in the average number of empowerment indicators that they were adequate in while the comparison group saw a decrease in average adequacy over time $(p=0.002)$ after controlling for age, sex, and level of education.

Conclusion: Despite starting at an empowerment disadvantage, the treatment group experienced gains in individual indicators of empowerment while the comparison group men and women experienced mixed results, with the women gaining, and the men losing empowerment. This research suggests that the BRB intervention may have

\footnotetext{
*Correspondence: benjamin_crookston@byu.edu

1 Department of Public Health, 2137 LSB, Brigham Young University,

Provo, UT 84606, USA

Full list of author information is available at the end of the article
}

(C) The Author(s) 2021. Open Access This article is licensed under a Creative Commons Attribution 4.0 International License, which permits use, sharing, adaptation, distribution and reproduction in any medium or format, as long as you give appropriate credit to the original author(s) and the source, provide a link to the Creative Commons licence, and indicate if changes were made. The images or other third party material in this article are included in the article's Creative Commons licence, unless indicated otherwise in a credit line to the material. If material is not included in the article's Creative Commons licence and your intended use is not permitted by statutory regulation or exceeds the permitted use, you will need to obtain permission directly from the copyright holder. To view a copy of this licence, visit http://creativecommons.org/licenses/by/4.0/. The Creative Commons Public Domain Dedication waiver (http://creativeco mmons.org/publicdomain/zero/1.0/) applies to the data made available in this article, unless otherwise stated in a credit line to the data. 
provided some protection for the treatment group when they faced an economic down-turn prior to the endline, indicative of household resilience. Future research should consider and strengthen relationships between resilience and empowerment.

Keywords: Burkina Faso, Women's health, Agricultural development, Women's empowerment

\section{Background}

Gender equality is recognized as a universal right and efforts aimed at increasing women's empowerment is a major global priority [1]. Kabeer defines women's empowerment as the process by which women expand their ability to make strategic life choices, especially in situations where this ability had been denied to them previously [2]. According to Kabeer, empowerment can be achieved through the following three dimensions: (1) resources-including education, social support, and assets, (2) agency - the ability to define goals and make decisions, and (3) achievements-well-being and life outcomes that result from the use of agency.

Despite a global focus on gender equality, many persistent factors contribute to the disempowerment of women. Many nations, for example, maintain laws that disempower women by restricting travel, limiting work opportunities outside the home, dictating what types of jobs women can have, and failing to provide legal protection against sexual harassment at work. Women are consistently paid less than men for the same work. Worldwide, women earn 0.77 cents for every dollar that men earn. In sub-Saharan Africa, the gender pay gap is 31 percent for women with children, compared to 4 percent for women without children [3]. While levels of female education and literacy have improved globally, limited educational opportunities perpetuate women's disempowerment, especially in sub-Saharan Africa where gender parity at all education levels (primary, lower secondary, and upper secondary) is far from realized [4]. According to UNESCO, 130 million girls between the ages of 6 and 17 were out of school in 2014. In addition, 15 million girls of primary school age-over half of them in sub-Saharan Africa-will never learn to read or write in primary school [5]. In 2017, women accounted for two-thirds of the world's 750 million illiterate adults [6]. Social and cultural norms related to early marriage and childbearing similarly persist and combine to thwart empowerment efforts. Despite being considered a human rights violation, child marriage remains common with an estimated 9 percent of females marrying before the age of 15 and another 25 percent marrying between the ages of 15 and $17[7,8]$. Child marriage is associated with early and rapid childbearing and reduced educational opportunities for the mother $[9,10]$. Multiple studies have identified an association between age at marriage and intimate partner violence (IPV) or gender-based violence (GBV) [11-14]. Lack of relationship power among young brides is considered to be a key moderating factor for risk of IPV/GBV $[15,16]$. The highest levels of child marriage occur collectively in sub-Saharan Africa, where 35 percent of women are married before the age of 18 [17].

Despite benefiting from historic and perpetual gender inequality and the subordination of women in the form of patriarchal privilege, some argue that men also experience disempowerment [18-20]. The very patriarchal structure and reinforcing gender norms keeping women subordinate may actually help to conceal the increasing disempowerment of men in parts of the world [21]. The socioeconomic consequences of unemployment, economic shocks, and natural disasters often effectively undermine men's perceived social value and self-esteem [21]. As men are unable to meet social and familial expectations, they may be met with contempt from women who are left with increasing burdens of responsibility [21]. While few, if any, would argue that men are comparatively disadvantaged to women-especially in terms of the consequences to disempowerment-men in resource-poor settings experience feelings of disempowerment and are exposed to the same gender stereotypes and cultural norms contributing to women's disempowerment. Efforts have increasingly been made to engage men in changing culturally reinforced gender stereotypes (i.e., Programme H from Promundo; Boys4Change from the Rwanda Men's Resource Centre; HeForShe $10 \times 10 \times 10$ ). Similarly, women's empowerment programs and efforts to decrease IPV that are inclusive of both men and women in gender re-norming efforts are growing (i.e., CARE's Cost of Violence against Women; Australia's Male Champions of Change; Oxfam's WECare). Gaining an increased understanding of the drivers of disempowerment for both women and men, and how the interplay of these contributing factors helps or hinders efforts to increase women's empowerment is imperative.

Developing and improving comprehensive measures of empowerment is critical to measuring progress towards gender equality. Currently, several tools measure gender equality and empowerment. The Gender Gap Index (GGI), Gender Development Index (GDI), and Gender Inequality Index (GII) are globallevel indices that rank countries based on the extent 
to which gender equality has been achieved. The GGI measures gender gaps in health, education, economy and politics [22]. The GDI assesses gender inequalities in health, knowledge, and living standards [23]. The GII measures gender gaps in reproductive health, empowerment, and economic status [24]. In addition, indices have been developed for Africa specifically. The African Gender Equality Index (AGEI) measures gender gaps in economic opportunities, human development, and law and institutions [25]. The African Gender and Development Index (AGDI) measures social power (capabilities), economic power (opportunities), and political power (agency) [26]. The Surveybased Women's emPowERment index (SWPER) Index, which allows within-country and between-country comparisons, measures attitudes towards violence, social independence, and decision making in Africa [27]. Some studies have used Demographic and Health Survey (DHS) data from African countries to measure women's empowerment and then performed exploratory [28] or confirmatory factor analysis $[29,30]$ to identify and confirm models of women's empowerment. Additional indices measure women's empowerment in agriculture. The Women's Empowerment in Agriculture Index (WEAI), which relies on household surveys with men and women, measures levels and trends in women's empowerment in agriculture at the national level [31]. The latest version of the WEAI, the project-level Women's Empowerment in Agriculture Index (pro-WEAI), measures the impact of agricultural development interventions on women's empowerment [32].

Agricultural development interventions present significant opportunities for expanding women's autonomy and empowerment. Women's empowerment influences agricultural productivity, food security, and health outcomes [33-35]. Less is known about how efforts to increase women's empowerment may or may not impact men's empowerment. The Building the Resilience of Vulnerable Communities in Burkina Faso (BRB) project is an integrated package of financial services, women's empowerment, nutrition, and agricultural programs provided to community-based women's savings group members. In particular, the BRB was designed to empower savings group members to overcome many of the social, geographic, economic, and cultural constraints that they experience during shocks and disasters. The main purpose of this study was to determine whether the BRB project improved women's and men's empowerment. Additionally, this study uses the pro-WEAI to examine and compare the main contributors of disempowerment for both women and men.

\section{Methods}

\section{Study design and setting}

This study conducted in Burkina Faso included 760 participants at baseline and 694 at endline split across treatment and comparison groups. The study is based on a longitudinal, quasi-experimental design. Sample size was determined based on an estimated attrition rate of $10 \%$ and power calculations for a $15 \%$ difference between control and treatment outcomes with 95\% confidence. In May 2016, survey teams collected baseline data through interviews with participants of the treatment group and the comparison group. In November 2017, survey teams collected endline data through interviews with the same participants from both groups. The treatment group participated in the BRB project and the comparison group did not.

\section{Participant characteristics}

The treatment group was composed of women savings group members (and their husband or main male household member) who lived in the Sanguié province of the Central-Western Region of Burkina Faso. The comparison group was composed of women savings group members (and their husband or main male household member) who lived in the Nayala province of the Boucle de Mouhoun Region of Burkina Faso. While the comparison group was selected because of proximity and general community similarities, there were key differences between the two groups at the individual level.

\section{Description of treatment}

An integrated set of financial services, women's empowerment, nutrition, and agricultural programs were provided to savings group members. Women farmers received support from local agricultural extension managers to assist in caring for crops and livestock. Trained staff facilitated learning conversations on gender dialogues, agriculture, and nutrition to encourage group members, their partners, and their communities to develop their own visions for change in gender relations, particularly as they related to land use for home gardens. Local financial organizations participating in the BRB project provided loan products (agriculture loans, microenterprise loans, and group loans) and ongoing support to SG members. Additional program details can be found elsewhere [36].

\section{Survey instrument}

The International Food Policy Research Institute developed the pro-WEAI to measure the impact of agricultural development interventions on women's empowerment. The quantitative and qualitative pro-WEAI instruments are open access and available elsewhere [37]. 
The pro-WEAI was translated into French and piloted in Burkina Faso in April 2016. The adapted version of pro-WEAI used in this study is based on 11 indicators. For each indicator, respondents are classified as adequate $(=1)$ or inadequate $(=0)$ based on predetermined thresholds. Pro-WEAI is composed of two subindices: the Three Domains of Empowerment sub-index (3DE), which measures the extent and depth of women's empowerment, and the Gender Parity sub-index (GPI), which measures gender parity between women and men in the same household based on their respective empowerment scores.

To assess women's and men's empowerment, we calculate (i) the individual's empowerment score, defined as the sum of the 11 pro-WEAI indicators; and (ii) the individual's empowerment status, which classifies an individual as empowered $(=1)$ if he or she achieves adequacy in at least 9 of the 11 indicators. To assess gender parity, we calculate (i) the intrahousehold inequality score, defined as the difference in the empowerment scores between the woman and her partner and equal to 0 if the woman is empowered; and (ii) the household's gender parity status, which classifies a household as achieving gender parity $(=1)$ if the woman is empowered or if her empowerment score is at least as high as the empowerment score of her partner. Table 1 outlines the 11 indicators used in the pro-WEAI for this study and describes the determination of adequacy for each indicator.

\section{Statistical analysis}

Frequency statistics were calculated and presented separately for treatment and comparison groups at both baseline and endline. Because the treatment and comparison groups were not similar at baseline, Differences-in-differences (DiD) modeling was used to estimate the impact of the BRB intervention on women's empowerment (PWI) after controlling for gender, age, and level of education. DiD estimates the differential effect of the treatment by calculating the average change in women's empowerment in the treatment and comparison groups from baseline to endline. This approach attempts to approximate an experimental design method by adjusting for differences in the outcome at baseline between comparison and treatment groups.

\section{Results}

Male respondents from the treatment group were significantly older than the comparison group male respondents (Table 2). Ever attended school and the proportion of respondents that were female were similar for both groups. While there was some loss to follow-up in both groups, demographic differences remained similar to baseline. Similarly, baseline demographics among the full BRB program evaluation survey show significant differences between the treatment and comparison groups [38]. The treatment group was ethnically more Gourounsi and Christian and less well-off economically and more food insecure, while the comparison group was more Mossi, Muslim, better-off economically, and more food secure.

At baseline, 38 percent of women and 36 percent of men in the treatment group were identified as empowered, compared to 44 percent of women and 75 percent of men in the comparison group (Table 3). At endline, the proportion of the treatment group achieving empowerment did not change from baseline for women, but improved substantially for men (47\%). Women from the comparison group saw an increase in empowerment at endline (51\%) while men saw a substantial decrease (67\%). Gender parity was high for households in both groups at baseline and increased slightly at endline. The intrahousehold inequality score was 26 percent for households in the treatment group and 21 percent for households in the comparison group. Both groups saw a slight decrease in the gap at endline.

Adequacy for each pro-WEAI indicator varied by gender, group, and time (Table 4). For example, women were more likely to be adequate in input in productive decisions, group membership, and membership in influential groups. Men were more likely to be adequate in attitudes about domestic violence, control over use of income, and work balance. Adequacy in attitudes about domestic violence improved for all groups over time while control of use of income decreased over time for all groups. Men and women across both the treatment and comparison groups lost adequacy in control over use of income at endline compared to baseline. While men and women in the treatment group lost adequacy in autonomy in income, men and women in the comparison group gained adequacy in autonomy in income. Women and men in the treatment group lost adequacy in work balance, women notably so, while men and women in the comparison group gained adequacy.

Among those classified as disempowered, the drivers of disempowerment remained similar for both the treatment and comparison groups (for both men and women) over time (Table 5). The main drivers included access and decisions on credit and finance, input in productive decisions, autonomy in income, and attitudes about domestic violence. Membership in influential groups was a larger driver at baseline than endline for treatment groups and was more likely to contribute to male disempowerment for both groups. Control over use of income as a contributor to disempowerment increased in all groups over time and was more likely to contribute to female disempowerment. Attitudes about domestic violence were 
Table 1 Indicators and measures of adequacy

\section{Autonomy in income}

A Relative Autonomy Index (RAl) score was calculated by summing responses to three vignettes about a person's motivation for how they use income generated from agricultural and non-agricultural activities. A participant was considered adequate in autonomy of income if they were more motivated by their own values than by coercion or fear of others' disapproval

\section{Attitudes about intimate partner violence against women}

Believes husband is NOT justified in hitting or beating his wife in all 5 scenarios:

1) She goes out without telling him

2) She neglects the children

3) She argues with him

4) She refuses to have sex with him

5) She burns the food

\section{Respect among household members}

Meets ALL of the following conditions related to their spouse, the other respondent, or another household member:

1) Respondent respects relation (MOST of the time) AND

2) Relation respects respondent (MOST of the time) AND

3) Respondent trusts relation (MOST of the time) AND

4) Respondent is comfortable disagreeing with relation (MOST of the time)

\section{Input in productive decisions}

Meets at least ONE of the following conditions for ALL of the agricultural activities they participate in

1) Makes related decision solely,

2) Makes the decision jointly and has at least some input into the decisions

3) Feels could make decision if wanted to (to at least a MEDIUM extent)

\section{Ownership of land and other assets}

Owns, either solely or jointly, at least ONE of the following:

1) At least THREE small assets (poultry, non-mechanized equipment, or small consumer durables)

2) At least TWO large assets

3) Land

\section{Access to and decisions on financial services}

Meets at least ONE of the following conditions:

1) Belongs to a household that used a source of credit in the past year AND participated in at least ONE sole or joint decision about it

2) Belongs to a household that did not use credit in the past year but could have if wanted to from at least ONE source

3) Has access, solely or jointly, to a financial account

\section{Control over use of income}

Has input in decisions related to how to use BOTH income and output from ALL of the agricultural activities they participate in AND has input in decisions related to income from ALL non-agricultural activities they participate in, unless no decision was made

\section{Work balance}

Works less than $10.5 \mathrm{~h}$ per day:

Workload = time spent in primary activity $+(1 / 2)$ time spent in childcare as a secondary activity

\section{Visiting important locations}

Meets at least ONE of the following conditions:

1) Visits at least TWO locations at least ONCE PER WEEK of [city, market, family/relative], or

2) Visits least ONE location at least ONCE PER MONTH of [health facility, public meeting]

\section{Group memberships}

Active member of at least ONE group

Membership in influential groups

Active member of at least ONE group that can influence the community to at least a MEDIUM extent

Table 2 Key demographics from respondents by treatment

\begin{tabular}{llllll}
\hline Indicator & $\begin{array}{l}\text { Treatment Female } \\
(\mathbf{n}=\mathbf{1 9 1})\end{array}$ & $\begin{array}{l}\text { Comparison } \\
\text { female } \\
(\mathbf{n}=\mathbf{1 8 9})\end{array}$ & $\boldsymbol{P}$ value & $\begin{array}{l}\text { Treatment Male } \\
(\mathbf{n}=\mathbf{1 9 1 )}\end{array}$ & $\begin{array}{l}\text { Comparison Male } \\
(\mathbf{n}=\mathbf{1 8 9})\end{array}$ \\
\hline $\begin{array}{l}\text { Mean age in years (SD, } \\
\text { min, max) }\end{array}$ & $43.5(11.8,21,76)$ & $42.1(11.2,18,68)$ & .2633 & $57.6(14.3,26,93)$ & $51.3^{*}(13.2,23,91)$ \\
\begin{tabular}{l} 
Ever attended school (\%) \\
\hline
\end{tabular} & 17.4 & 13.9 & .375 & 18.5 & 20.8 \\
\hline
\end{tabular}


Table 3 pro-WEAI results by gender, treatment, and time

\begin{tabular}{|c|c|c|c|c|c|c|c|c|}
\hline \multirow[b]{3}{*}{ Indicator } & \multicolumn{4}{|l|}{ Baseline } & \multicolumn{4}{|l|}{ Endline } \\
\hline & \multicolumn{2}{|c|}{ Treatment (\%) } & \multicolumn{2}{|c|}{ Comparison (\%) } & \multicolumn{2}{|c|}{ Treatment (\%) } & \multicolumn{2}{|c|}{ Comparison (\%) } \\
\hline & Female & Male & Female & Male & Female & Male & Female & Male \\
\hline Empowerment Score & 0.69 & 0.71 & 0.76 & 0.89 & 0.72 & 0.77 & 0.79 & 0.86 \\
\hline Achieving empowerment (\%) & 38 & 36 & 44 & 75 & 38 & 47 & 51 & 67 \\
\hline Gender Parity Index & 0.88 & & 0.90 & & 0.90 & & 0.93 & \\
\hline Average empowerment gap & 0.26 & & 0.21 & & 0.25 & & 0.20 & \\
\hline
\end{tabular}

Respondents with missing indicators are dropped from the sample

Table 4 Adequacy status for PRO-WEAl indicators by sex, treatment, and time

\begin{tabular}{|c|c|c|c|c|c|c|c|c|}
\hline \multirow[b]{3}{*}{ Indicators } & \multicolumn{4}{|l|}{ Baseline } & \multicolumn{4}{|l|}{ Endline } \\
\hline & \multicolumn{2}{|c|}{ Treatment (\%) } & \multicolumn{2}{|c|}{ Comparison (\%) } & \multicolumn{2}{|c|}{ Treatment (\%) } & \multicolumn{2}{|c|}{ Comparison (\%) } \\
\hline & Female & Male & Female & Male & Female & Male & Female & Male \\
\hline Autonomy in income & 62.8 & 60.7 & 44.4 & 66.1 & 30.7 & 48.2 & 58.2 & 69.6 \\
\hline Attitudes about domestic violence & 37.7 & 67.0 & 22.2 & 57.7 & 48.9 & 70.8 & 52.2 & 75.6 \\
\hline Respect among household members & 89.5 & 91.6 & 95.2 & 94.7 & 97.1 & 99.4 & 96.0 & 99.4 \\
\hline Input in productive decisions & 33.0 & 5.2 & 46.0 & 32.8 & 47.7 & 13.1 & 39.6 & 22.6 \\
\hline Ownership of land and other assets & 88.5 & 99.0 & 96.8 & 100 & 97.2 & 100 & 98.4 & 100 \\
\hline Access / decisions on credit / finance & 8.9 & 11.5 & 13.2 & 21.7 & 18.2 & 16.1 & 8.2 & 19.1 \\
\hline Control over use of income & 62.3 & 91.6 & 67.7 & 95.8 & 39.2 & 71.4 & 37.4 & 62.5 \\
\hline Work balance & 62.8 & 77.5 & 54.5 & 87.3 & 37.5 & 69.6 & 75.8 & 91.1 \\
\hline Visiting important locations & 78.0 & 79.1 & 92.1 & 87.3 & 86.4 & 86.3 & 91.8 & 80.4 \\
\hline Group membership & 75.4 & 58.1 & 97.9 & 91.5 & 98.9 & 78.0 & 95.1 & 82.1 \\
\hline Membership in influential groups & 70.2 & 54.5 & 95.8 & 90.5 & 86.9 & 70.8 & 94.5 & 80.4 \\
\hline
\end{tabular}

Table 5 Contributors to disempowerment by sex, treatment, and time

\begin{tabular}{|c|c|c|c|c|c|c|c|c|}
\hline \multirow[b]{3}{*}{ Indicators } & \multicolumn{4}{|l|}{ Baseline } & \multicolumn{4}{|l|}{ Endline } \\
\hline & \multicolumn{2}{|c|}{ Treatment (\%) } & \multicolumn{2}{|c|}{ Comparison (\%) } & \multicolumn{2}{|c|}{ Treatment (\%) } & \multicolumn{2}{|c|}{ Comparison (\%) } \\
\hline & Female & Male & Female & Male & Female & Male & Female & Male \\
\hline Autonomy in income & 8.3 & 9.5 & 13.5 & 14.2 & 15.5 & 15.1 & 11.4 & 8.3 \\
\hline Attitudes about domestic violence & 14.3 & 7.8 & 18.5 & 14.2 & 12.7 & 8.5 & 13.9 & 9.8 \\
\hline Respect among household members & 2.9 & 2.7 & 1.4 & 3.2 & 0.9 & 0.2 & 1.5 & 0.4 \\
\hline Input in productive decisions & 14.9 & 19.9 & 16.3 & 17.8 & 14.4 & 19.5 & 18.5 & 18.9 \\
\hline Ownership of land and other assets & 3.2 & 0.3 & 1.0 & 0.0 & 0.9 & 0.0 & 0.7 & 0.0 \\
\hline Access / decisions on credit / finance & 17.4 & 18.9 & 19.3 & 20.5 & 17.0 & 19.1 & 20.4 & 19.3 \\
\hline Control over use of income & 10.0 & 2.2 & 11.6 & 2.3 & 15.1 & 7.8 & 17.8 & 9.4 \\
\hline Work balance & 8.5 & 5.6 & 13.5 & 4.1 & 15.1 & 6.8 & 8.5 & 3.1 \\
\hline Visiting important locations & 5.1 & 6.0 & 2.6 & 9.1 & 3.7 & 4.5 & 3.2 & 9.1 \\
\hline Group membership & 6.9 & 13.0 & 0.8 & 6.8 & 0.4 & 8.2 & 1.9 & 10.2 \\
\hline Membership in influential groups & 8.5 & 14.1 & 1.4 & 7.8 & 4.1 & 10.4 & 2.2 & 11.4 \\
\hline
\end{tabular}


larger contributors to disempowerment for women than men and decreased slightly over time.

Differences-in-differences (DID) modeling was used to estimate the change in adequacy across the 11 empowerment indicators as a result of the BRB intervention (Table 6). Participants from the treatment group reported an increase in the average number of empowerment indicators that they were adequate in while the comparison group saw a decrease in average adequacy over time $(\mathrm{p}=0.002)$ after controlling for age, sex, and level of education.

\section{Discussion}

Notwithstanding an economic downturn resulting from a significant drought and subsequent poor harvest that occurred at the time of the endline survey [36], this study provides valuable insights related to women's and men's empowerment. Results of the pro-WEAI reveal that women in the comparison group experienced greater improvements in empowerment over time. Results for men were remarkably different: men in the treatment group experienced an improvement in empowerment while men in the comparison group experienced a substantial decline in empowerment.

Women in both the treatment and comparison groups gained in gender parity over time; however, the gain experienced by the comparison group may have been affected by men's loss of empowerment. Men and women in the treatment group started out with an empowerment disadvantage, compared to the comparison group, and maintained this disadvantage at the endline. This is consistent with findings from the full BRB program evaluation baseline which found that the treatment group also started out with a disadvantage in economic outcomes and food security [36]. However, it is important to note that when assessing individual adequacy scores and adjusting for baseline, sex, age, and education, results indicate the treatment group made greater gains in individual indicators of empowerment, even though this did not result in them passing the thresholds for classifying them as empowered.

Table 6 Difference-in-differences in adequacy

\begin{tabular}{|c|c|c|c|}
\hline \multirow[t]{2}{*}{ Time } & \multirow[t]{2}{*}{ Treatment mean (SD) } & \multicolumn{2}{|l|}{ Condition } \\
\hline & & $\begin{array}{l}\text { Comparison } \\
\text { mean (SD) }\end{array}$ & Difference \\
\hline Baseline & $6.82(1.68)$ & $7.76(1.46)$ & 0.94 \\
\hline Endline & $7.03(1.46)$ & $7.61(1.45)$ & 0.58 \\
\hline Change & 0.21 & -0.15 & $0.36^{*}$ \\
\hline
\end{tabular}

${ }^{*} p=0.002$, controls for sex, age and education
Regions where the study took place experienced a significant economic downturn due to a drought resulting in poor harvests. While much of the literature on gender and climate change suggest that women are disproportionately and negatively impacted by climate-change or weather events compared to men [39], these results suggest that some interventions geared toward women may be protective of men as well. Men in the comparison group may have lost some confidence in their ability to withstand this downturn. The engagement of women in both the treatment and comparison groups in the savings groups may have contributed to sustained or improved empowerment.

Though the relationship between male empowerment and household economics is not well documented, global patterns of male participation in the labor force demonstrate income generating obligations predominantly are carried out by men [40]. Further, many men see their primary societal role as providing for their respective household [41]. Hence, men's self-esteem is often tied directly to employment as noted by ProMundo's State of the World's Fathers 2019 report. Not surprisingly then, when men are underemployed, risk of GBV for women in the household increases [42, 43].

Some key drivers of disempowerment were similar across time, groups, and sex. For example, decisions on credit and finance, input in productive decisions, and autonomy in income were major contributors of disempowerment for all groups and times. These findings suggest that household economics contributed most to the disempowerment of this population. This is consistent with other qualitative and quantitative results, both from the qualitative assessment conducted for the BRB project [44] and elsewhere [32, 45-47].

Women participating in savings groups alone are more likely to see increased incomes and savings, economic independence [48], better balancing of spending and saving, improved or varied livelihood activities [49], and better commercial results [50]. In short, participation in savings groups positively impacts women's economic, social, and political empowerment. Finally, it is important to note that savings groups have also not been found to adversely affect reports of domestic violence [51].

Contrary to research that indicates men have more decision-making power and access to resources [52, 53], men were also found to be disempowered in decisions on credit and finance, input in productive decisions, and autonomy in income. In 2017, the World Bank reported a 17 percentage-point gender gap between women's and men's access to bank accounts in Burkina Faso; 51 percent of men had a bank account compared to 34 percent of women [52]. Men and women borrowed from financial institutions at a similarly low rate 
of 9 percent. In this study, women's disempowerment in the treatment group was driven slightly less by access to financial services when compared to their spouses at the endline [36].

Women's access to credit, in particular, is fraught with challenges. Though it increases opportunities for economic improvement for women, it also can lead to anxiety and struggle, especially in situations where women may carry repayment responsibility though they may not actually make decisions on the use of the loan. This can be addressed, at least in part, through savings groups that give women opportunities to protect their money from partners [54].

While some contributors to disempowerment were similar for men and women, some contributors did differ by sex. For example, attitudes about GBV were more likely to contribute to female disempowerment. That is to say that women in this study were more likely than men to indicate a husband is justified in hitting or beating his wife for going out without telling him, neglecting the children, arguing with him, refusing to have sex with him, or burning the food. These results are similar to findings from previous research on the pro-WEAI [32] and the literature [55] from numerous Sub-Saharan African countries where women were more likely to rationalize GBV than men. While increasing women's own condemnation of GBV is an important attitudinal shift, research on strategies to reduce GBV have found that efforts to influence the intra-household distribution of economic resources, promotion of gender equitable norms, promotion of joint decision-making and increasing coverage of messages (such as through media) to the general public regarding alternatives to violence as a means to resolve conflict are strategies proven to reduce the likelihood of GBV [56-60]. Peacock and Barker note that one way to address GBV is by targeting men through women's economic empowerment initiatives [61]. A study conducted in Rwanda by CARE-Rwanda and ProMundo compared a control group (savings groups of women where men were not deliberately included) to savings groups of men-only and savings groups where couples were engaged and found that engaging men led to more equitable household decision-making, decreased couple conflict, increased communication, and higher income gains for families [62]. Peacock and Barker also suggest that policies aimed at ending GBV by engaging men should 1) promote human rights, including rights of women and girls; 2) remain accountable to and in dialogue with women's rights movements and organizations, 3) enhance men's and boy's lives, 4) be inclusive and responsive to diversities among men, and 5), address the social and structural determinants of gender inequalities [61].

\section{Implications, recommendations, and future research}

The pro-WEAI index works to measure empowerment by efficiently considering a number of multifaceted factors while also allowing researchers, evaluators, and practitioners to understand the contributions of individual factors towards establishing empowerment. The results from this assessment leveraging the pro-WEAI suggest that future programs that aim to improve women's economic empowerment should ensure a meaningful engagement of men, particularly as it relates to the formation of savings groups' access and use of credit, as well as to address GBV. Men need to feel they have a seat at the table as well as a positive role in the empowerment of their wives, daughters, and other women close to them.

Given the concern of financial abuse or increase of stress carried by women when they carry the household debt, future iterations of the pro-WEAI may seek to balance the current focus on access to and use of credit with the responsibility for repayment and the stress they feel carrying this responsibility. While savings groups and microfinance-based strategies often focus on new product or channel development with little recognition of the role that stresses and shocks related to GBV or conflict and instability at the household or community levels play in the lives of poor women, this is an important area for further innovation.

Addressing GBV requires not only addressing those who perpetrate it (men), but also those who justify it (more often women). Incorporating approaches that have been shown to mitigate the risk of and decrease genderbased violence should be scaled up, including approaches such as gender and community dialogues and approaches that increase intra-household distribution of economic resources and cooperation. Finally, women's empowerment cannot come at the disempowerment of men. While gender equality assumes women need to "catch up" it is also possible that men can "fall back" to the detriment of women and men alike. Particularly among poor populations, as has been shown here, men are almost equally disempowered. Additional research is needed to understand the negative consequence of male empowerment, not just on themselves, as is often done for women, but on the household as a whole, particularly since a key risk of potential male disempowerment is the resort to GBV as a stronghold on control of the resources and people that surround a male primary income earner.

Our study had some limitations. First, the noted economic downturn at the endline posed a challenge to this study and results have to be interpreted with this limitation in mind. Another round of data collection for the 
BRB program evaluation, that was unable to include the pro-WEAI, did occur one year after the pro-WEAI endline and the results were suggestive of much stronger impacts for the treatment group, particularly as they bounced back from the economic downturn [37]. Second, while it was originally planned that the full BRB program evaluation would be integrated with the proWEAI survey to provide additional demographic and household data, this was not possible due to lack of consistent household identifiers. Hence, the main controls (age, gender, and education) used in the analysis were the only relevant controls available. A more complete appraisal of the differences between the comparison and treatment groups can be found in the full evaluation report [36]. Next, there were key differences between the comparison and treatment groups. While analytical methods were chosen to account for these differences, making comparisons must be considered in the context of these key differences. Finally, all women participating in this study were members of self-help groups that also may have received other non-financial services before or during the program period. Women's very membership in savings groups also receiving other interventions may also cloud the ability to tease out the impacts of the BRB program's agricultural, nutrition, and women's empowerment interventions.

\section{Conclusion}

The pro-WEAI data suggests that men and women of the treatment group experienced statistically significant gains in adequacy across individual pro-WEAI indicators, even though this did not translate into passing thresholds to be considered improvements in empowerment. While women in the comparison group saw gains in empowerment, men in the comparison group experienced losses in empowerment. This research suggests that the BRB intervention may have provided some protection for men and women in the treatment group when they faced an economic down-turn prior to the endline, indicative of household resilience. Leder suggests that there may be a relationship between empowerment and resilience, particularly once the extent to which each dimension or indicator of empowerment influences resilience is determined. This is an opportunity for future research [63].

To understand the influence of a multiple-intervention project designed to influence women's economic empowerment, the pro-WEAI has been found to be a useful tool for identifying priorities for improving empowerment suggesting a "stay the course" for some already-implemented interventions such as the expansion of agriculture and income-generating activity credit and an expansion of other interventions such as the gender dialogues to take a stronger emphasis on attitudes towards GBV.

\section{Abbreviations}

3DE: Three Domains of Empowerment sub-index; AGDI: African Gender and Development Index; AGEl: African Gender Equality Index; BRB: Building the Resilience of Vulnerable Communities in Burkina Faso; DiD: Difference-in-Difference; DHS: Demographic and Health Survey; GBV: Gender-based violence; GDI: Gender Development Index; GGI: Gender Gap Index; GIl: Gender Inequality Index; GPI: Gender Parity sub-index (GPI); IPV: Intimate partner violence; pro-WEAl: Project-level Women's Empowerment in Agriculture Index; RM-TWG : Resilience Measurement Technical Working Group; SWPER: Survey-based Women's emPowERment index; WEAl: Women's Empowerment in Agriculture Index.

\section{Acknowledgements}

We would like to thank Office de Développement des Eglises Evangéliques and Lessokon Sarl for their contribution to this research.

\section{Authors' contributions}

BC designed the study, led the analysis and interpretation of the data, and revision of the manuscript. JW contributed to the analysis and interpretation of data, and revision of the manuscript. SD and $\mathrm{CH}$ contributed to interpretation of data and revision of the manuscript. GS contributed to the analysis and interpretation of the data and revision of the manuscript. BG contributed to the design, analysis, interpretation of data and revision of the manuscript. All authors read and approved the final manuscript.

\section{Funding}

This research was supported by funding from Margaret A. Cargill Philanthropies and undertaken as part of the Gender, Agriculture, and Assets Project Phase Two (GAAP2). Funding support to GAAP2 was provided by the Bill \& Melinda Gates Foundation (BMGF) [Grant Number: INV-008977], the United States Agency for International Development (USAID) [Grant Number: EEM-G00-04-00013-00], and the CGIAR Research Program on Agriculture for Nutrition and Health (A4NH). Neither the GAAP2 funders nor the Margaret A. Cargill Philanthropies played a role in the design of the study and collection, analysis, and interpretation of data and in writing the manuscript.

\section{Availability of data and materials}

The datasets used during the current study are available from the corresponding author on reasonable request.

\section{Declarations}

\section{Ethics approval and consent to participate}

This study was approved by the research institutional review board for Brigham Young University (Ref: X16090). Written consent was obtained from all participants included in the study.

\section{Consent for publication}

Not applicable.

\section{Competing interests}

BG is an employee of Grameen Foundation and was the internal evaluator for this program. No author declares a competing interest. GS is a member of the GAAP2 team and was an advisor for data evaluation. GS and the GAAP2 team provided input into the study design, analysis, and interpretation of the data.

\section{Author details}

'Department of Public Health, 2137 LSB, Brigham Young University, Provo, UT 84606, USA. ${ }^{2}$ International Food Policy Research Institute, 1201 I Street, NW, Washington, DC 20005, USA. ${ }^{3}$ Grameen Foundation, 1400 K Street NW, Suite 550, Washington, DC 20005, USA. 
Received: 8 October 2020 Accepted: 24 May 2021

Published online: 03 June 2021

\section{References}

1. United Nations. Goal 5: Achieve gender equality and empower all women and girls. n.d. https://www.un.org/sustainabledevelopment/ gender-equality/. Accessed 30 Apr 2020.

2. Kabeer N. Resources, agency, achievements: reflections on the measurement of women's empowerment. Dev Change. 1999;30(3):435-64. https://doi.org/10.1111/1467-7660.00125.

3. United Nations Economic and Social Council. Women's economic empowerment in the changing world of work: report of the secretarygeneral. 2016. https://www.un.org/ga/search/view_doc.asp?symbol=E/ CN.6/2017/3. Accessed 29 Apr 2020.

4. United Nations Educational, Scientific, and Cultural Organization (UNESCO). Global education monitoring report 2019: gender report: building bridges for gender equality. 2019. https://unesdoc.unesco.org/ ark:/48223/pf0000368753. Accessed 29 Apr 2020.

5. United Nations Educational, Scientific, and Cultural Organization (UNESCO) Institute for Statistics (UIS). Policy paper 27/fact sheet 37: leaving no one behind: how far on the way to universal primary and secondary education? 2016. https://unesdoc.unesco.org/ark:/48223/pf0000245238. Accessed 29 Apr 2020

6. United Nations Educational, Scientific, and Cultural Organization (UNESCO) Institute for Statistics (UIS). Fact sheet no. 45: literacy rates continue to rise from one generation to the next. 2017. http://uis.unesco. $\mathrm{org} / \mathrm{sites} /$ default/files/documents/fs45-literacy-rates-continue-rise-gener ation-to-next-en-2017_0.pdf. Accessed 2 May 2020.

7. Kidman R. Child marriage and intimate partner violence: a comparative study of 34 countries. Int J Epidemiol. 2017;46(2):662-75. https://doi.org/ 10.1093/ije/dyw225.

8. United Nations Children's Fund (UNICEF). Child marriage and the law: legislative reform initiative paper series. New York, NY: United Nations Children's Fund (UNICEF), Gender, Rights and Civic Engagement Section, Division of Policy and Practice; 2007. https://www.unicef.org/french/files/ Child_Marriage_and_the_Law.pdf. Accessed 26 August 2020.

9. Dommaraju P. Marriage age and fertility dynamics in India. Asia Pac Popul J. 2011;26(2):21-38. https://doi.org/10.18356/dcf9f3c9-en.

10. Raj A, Saggurti N, Balaiah D, Silverman JG. Prevalence of child marriage and its effects on fertility and fertility-control outcomes of young women in India: a cross-sectional, observational study. Lancet. 2009;373(9678):1883-9. https://doi.org/10.1016/S0140-6736(09)60246-4.

11. Hindin MJ, Kishor S, Ansara DL. Intimate partner violence among couples in 10 DHS countries: predictors and health outcomes. DHS Analytical Studies No. 18. Calverton, Maryland, USA: Macro International Inc; 2008. https://dhsprogram.com/pubs/pdf/AS18/AS18.pdf. Accessed 26 Aug 2020.

12. Le Hong MT, Tran TD, Nguyen HT, Fisher J. Early marriage and intimate partner violence among adolescents and young adults in Viet Nam. J Interpers Violence. 2014;29(5):889-910. https://doi.org/10.1177/08862 60513505710

13. Rocca C, Rathod S, Falle T, Pande R, Krishnan S. Challenging assumptions about women's empowerment: social and economic resources and domestic violence among young married women in urban South India. Int J Epidemiol. 2009:38(2):577-85. https://doi.org/10.1093/ije/dyn226.

14. Speizer IS, Pearson E. Association between early marriage and intimate partner violence in India: a focus on youth from Bihar and Rajasthan. J Interpers Violence. 2011;26(10):1963-81. https://doi.org/10.1177/08862 60510372947

15. Heise L, Ellsberg M, Gottmoeller M. A global overview of gender-based violence. Int J Gynaecol Obstet. 2002;78(Suppl 1):S5-14. https://doi.org/ 10.1016/S0020-7292(02)00038-3.

16. Mathur S, Greene M, Malhotra A. Too young to wed: the lives, rights and health of young married girls. Washington, DC: International Center for Research on Women; 2003. https://www.issuelab.org/resources/11421/ 11421.pdf. Accessed 26 Aug 2020.

17. United Nations Children's Fund (UNICEF). Child marriage. 2020. https:// data.unicef.org/topic/child-protection/child-marriage/. Accessed 26 Aug 2020.
18. Silberschmidt M. Have men become the weaker sex? Changing life situations in Kisii District. Kenya J Mod Afr Stud. 1992;30(2):237-53. https://doi. org/10.1017/S0022278X00010703.

19. Chant S, Gutman M. 'Men-streaming' gender? Questions of gender and development policy in the twenty-first century. Prog Dev Stud. 2002;2(4):269-82. https://doi.org/10.1191/1464993402ps041ra.

20. Wanner T, Wadham B. Men and masculinities in international development: 'men-streaming'gender and development? Dev Policy Rev. 2015;33(1):15-32. https://doi.org/10.1111/dpr.12090.

21. Silberschmidt M. Disempowerment of men in rural and urban East Africa: implications for male identity and sexual behavior. World Dev. 2001;29(4):657-71. https://doi.org/10.1016/S0305-750X(00)00122-4.

22. World Economic Forum. The global gender gap report 2014. 2014. http:// www3.weforum.org/docs/GGGR14/GGGR_CompleteReport_2014.pdf. Accessed 2 May 2020.

23. United Nations Development Programme (UNDP). Gender Development Index (GDI). n.d. http://hdr.undp.org/en/content/gender-developmentindex-gdi. Accessed 2 May 2020.

24. United Nations Development Programme (UNDP). Gender Inequality Index (GII). n.d. http://hdr.undp.org/en/content/gender-inequality-indexgii. Accessed 2 May 2020.

25. African Development Bank Group. Empowering African women: an agenda for action: Africa Gender Equality Index 2015. 2015. https://www. afdb.org/fileadmin/uploads/afdb/Documents/Publications/African_ Gender_Equality_Index_2015-EN.pdf. Accessed 2 May 2020.

26. Economic Commission for Africa. The African Gender and Development Index 2011. 2011. https://www.uneca.org/sites/default/files/Publicatio nFiles/agdi_2011_eng_fin.pdf. Accessed 2 May 2020.

27. Ewerling F, Lynch J, Victora CG, Van Eerdewijk A, Tyszler M, Barros AJD. The SWPER index for women's empowerment in Africa: development and validation of an index based on survey data. Lancet Glob Health. 2017;5(9):e916-23. https://doi.org/10.1016/S2214-109X(17)30292-9.

28. Phan L. Measuring women's empowerment at household level using DHS data of four Southeast Asian Countries. Soc Indic Res. 2016;126:35978. https://doi.org/10.1007/s11205-015-0876-y.

29. Miedema SS, Haardörfer R, Girard AW, Yount KM. Women's empowerment in East Africa: development of a cross-country comparable measure. World Dev. 2018;110:453-64. https://doi.org/10.1016/j.worlddev.2018.05. 031.

30. Asaolu IO, Alaofè H, Gunn JKL, Adu AK, Monroy AJ, Ehiri JE, Hayden MH, Ernst KC. Measuring women's empowerment in sub-Saharan Africa: exploratory and confirmatory factor analyses of the demographic and health surveys. Front Psychol. 2018;9:994. https://doi.org/10.3389/fpsyg. 2018.00994.

31. Alkire S, Meinzen-Dick R, Peterman A, Quisumbing A, Seymour G, Vaz A. The Women's Empowerment in Agriculture Index. Oxford Poverty \& Human Development Initiative (OPHI). 2013;52:71-91. https://www.ophi. org.uk/wp-content/uploads/ophi-wp-58.pdf. Accessed 18 June 2020.

32. Malapit H, Quisumbing A, Meinzen-Dick R, Seymour G, Martinez E, Heckert J, Rubin D, Vaz A, Yount K. Development of the project-level Women's Empowerment in Agriculture Index (pro-WEAI). World Dev. 2019;122:675-92. https://doi.org/10.1016/j.worlddev.2019.06.018.

33. Diiro GM, Seymour G, Kassie M, Muricho G, Muriithi BW. Women's empowerment in agriculture and agricultural productivity: evidence from rural maize farmer households in western Kenya. PLOS ONE. 2018;13(5):e0197995. https://doi.org/10.1371/journal.pone.0197995.

34. Quisumbing AR, Maluccio JA. Resources at marriage and intrahousehold allocation: evidence from Bangladesh, Ethiopia, Indonesia, and South Africa. Oxford Bull Econ Stat. 2003;65(3):283-327. https://doi.org/10.1111/ 1468-0084.t01-1-00052.

35. Haddad L, Hoddinott J. Women's income and boy-girl anthropometric status in the Côte d'Ivoire. World Dev. 1994;22(4):543-53. https://doi.org/ 10.1016/0305-750X(94)90110-4.

36. Crookston B, Hall C, West J, Gray B, Bardsley A. Building resilience in Burkina Faso: longitudinal assessment results. Washington, DC: Grameen Foundation; 2019. https://grameenfoundation.org/documents/BRB_ Impact_Report_Final_060619.pdf. Accessed 17 June 2020.

37. International Food Policy Research Institute. WEAl guides and instruments. 2020. http://weai.ifpri.info/weai-resource-center/guides-and-instr uments/. Accessed 15 October 2020. 
38. Gash M. Leveraging services to create new pathways: impact study baseline results from the initiative building resilience in Burkina Faso. Washington, DC: Grameen Foundation; 2017. https://grameenfoundati on.org/documents/BRB_Impact_Study_Baseline_Report_30Jan2017.pdf. Accessed May 20, 2019.

39. Nelson V, Meadows K, Cannon T, Morton J, Martin A. Uncertain predictions, invisible impacts, and the need to mainstream gender in climate change adaptations. Gend Devel. 2002;10(2):51-9. https://doi.org/10. 1080/13552070215911.

40. Kabeer N. Women's economic empowerment and inclusive growth: labour markets and enterprise development. (SIGI working paper 2012/1). United Kingdom Department for International Development \& International Development Research Centre; 2012. https://www.idrc. ca/sites/default/files/sp/Documents\%20EN/NK-WEE-Concept-Paper.pdf. Accessed 9 Sept 2020.

41. van der Gaag N, Heilman B, Gupta T, Nembhard C, Barker G. State of the world's fathers: unlocking the power of men's care. Washington, DC: Promundo-US; 2019. https://s30818.pcdn.co/wp-content/uploads/2019/ 05/BLS19063_PRO_SOWF_REPORT_015.pdf. Accessed 17 June 2020.

42. Cunradi CB, Todd M, Duke M, Ames G. Problem drinking, unemployment, and intimate partner violence among a sample of construction industry workers and their partners. J Fam Violence. 2009;24(2):63-74. https://doi. org/10.1007/s10896-008-9209-0.

43. Tur-Prats A. Unemployment and intimate-partner violence: a genderidentity approach (Barcelona GSE working paper 963). Barcelona, Spain: Barcelona Graduate School of Economics; 2017. https://www.barcelonag se.eu/sites/default/files/working_paper_pdfs/963.pdf. Accessed 18 June 2020

44. Kieran C, Gray B, Gash M. Understanding gender norms in rural Burkina Faso: a qualitative assessment. Washington, DC: Grameen Foundation; 2018. https://grameenfoundation.org/documents/Understanding_ Gender_Norms_Baseline_Qualitative_Assessment_BRB.pdf. Accessed 17 June 2020.

45. Meinzen-Dick R, Rubin D, Elias M, Mulema AA, Myers E. Women's empowerment in agriculture: lessons from qualitative research (IFPRI Discussion Paper 01797). Washington, DC: International Food Policy Research Institute; 2019. https://www.idrc.ca/sites/default/files/sp/Documents\% 20EN/NK-WEE-Concept-Paper.pdf. Accessed 18 June 2020.

46. Johnson NL, Kovarik C, Meinzen-Dick R, Njuki J, Quisumbing A. Gender, assets, and agricultural development: lessons from eight projects. World Dev. 2016;83:295-311. https://doi.org/10.1016/j.worlddev.2016.01.009.

47. Yount KM, Cheong YF, Maxwell L, Heckert J, Martinez EM, Seymour G. Measurement properties of the project-level Women's Empowerment in Agriculture Index. World Dev. 2019;124:104639. https://doi.org/10.1016/j. worlddev.2019.104639.

48. Rickard K, Johnsson A. Women's Empowerment and savings groups: what do we know? Washington, DC: Seep Network; 2019. https://seepnetwork. org/Resource-Post/Women-s-Empowerment-and-Savings-Groups-WhatDo-We-Know. Accessed 26 August 2020

49. Gash M, Odell K. The evidence-based story of savings groups: a synthesis of seven randomized control trials. Washington, DC: The SEEP Network; 2013. https://www.freedomfromhunger.org/sites/default/files/FINAL_ Evidence-Based_Savings_Web.pdf. Accessed 29 August 2020

50. Karlan D, Savonitto B, Thuysbaert B, Udry C. Impact of savings groups on the lives of the poor. Proc Natl Acad Sci USA. 2017;114(12):3079-84. https://doi.org/10.1073/pnas.1611520114.
51. Brody C, De Hoop T, Vojtkova M, Warnock R, Dunbar M, Murthy P, Dworkin SL. Economic self-help group programmes for improving women's empowerment: a systematic review, 3ie Systematic Review 23. London: International Initiative for Impact Evaluation (3ie); 2016. http://www.3ieim pact.org/sites/default/files/2019-01/sr23-self-help-group-review.pdf

52. Demirgüç-Kunt $A$, Klapper $L$, Singer D, Ansar $S$, Hess J. Global Findex database 2017: measuring financial inclusion and the Fintech revolution. Washington, DC: World Bank; 2018.

53. Morsy H, Youssef H. Access to Finance-Mind the Gender Gap. (EBRD Working Paper 202). London, England: European Bank for Reconstruction and Development; 2017. https://www.ebrd.com/publications/workingpapers/access-to-finance. Accessed 12 Sept 2020.

54. Kono H, Tanaka T. Does marriage work as a savings commitment device? Experimental evidence from Vietnam. PLoS ONE. 2019;14(6):e0217646. https://doi.org/10.1371/journal.pone.0217646.

55. Uthman O, Lawoko S, Moradi T. Factors associated with attitudes towards intimate partner violence against women: a comparative analysis of 17 sub-Saharan countries. BMC Int Health Hum Rights. 2009;9(14):1-15. https://doi.org/10.1186/1472-698X-9-14.

56. Vanderende KE, Sibley LM, Cheong YF, Naved RT, Yount KM. Community economic status and intimate partner violence against women in Bangladesh: Compositional or contextual effects? Violence Against Women. 2015;21(6):679-99. https://doi.org/10.1177/1077801215576938.

57. Heise LL. What works to prevent partner violence? An evidence overview. London: STRIVE Research Consortium, London School of Hygiene and Tropical Medicine; 2011. https://www.oecd.org/derec/49872444.pdf. Accessed 18 June 2020.

58. Usdin S, Scheepers E, Goldstein S, Japhet G. Achieving social change on gender-based violence: a report on the impact evaluation of Soul City's fourth series. Soc Sci Med. 2005;61(11):2434-45. https://doi.org/10.1016/j. socscimed.2005.04.035

59. Clark CJ, Shrestha B, Ferguson G, Shrestha PN, Calvert C, Gupta J, Batayeh B, Bergenfeld I, Oakes JM. Impact of the Change Starts at Home Trial on women's experience of intimate partner violence in Nepal. SSM Popul Health. 2020;10:100530. https://doi.org/10.1016/j.ssmph.2019.100530.

60. Yount KM, James-Hawkins L, Cheong YF, Naved RT. Men's violence perpetration in Bangladesh: community gender norms and violence in childhood. Psychol Men Masc. 2018;19(1):117-30. https://doi.org/10. 1037/men0000069.

61. Peacock D, Barker G. Working with men and boys to prevent genderbased violence: principles, lessons learned, and ways forward. Men Masc. 2014;17(5):578-99.

62. Slegh H, Barker G, Kimonyo A, Ndolimana P, Bannerman M. 'I can do women's work': reflections on engaging men as allies in women's economic empowerment in Rwanda. Gend Dev. 2013;21(1):15-30. https:// doi.org/10.1080/13552074.2013.767495.

63. Leder S. Linking women's empowerment and their resilience: literature review. Building Resilience and Adaptation to Climate Extremes and Disasters (BRACED) Programme. London: Overseas Development Institute. 2015. http://www.braced.org/contentAsset/raw-data/2c7330b8-012447a7-b3bf-211cd121d629/attachmentFile. Accessed 9 Sept 2020

\section{Publisher's Note}

Springer Nature remains neutral with regard to jurisdictional claims in published maps and institutional affiliations. 